\title{
Effect of Large-scale Biomass Burning on Aerosol Optical Properties at the GAW Regional Station Pha Din, Vietnam
}

\author{
Nicolas Bukowiecki ${ }^{1 * \dagger \dagger}$, Martin Steinbacher ${ }^{2}$, Stephan Henne ${ }^{2}$, Nhat Anh Nguyen ${ }^{3}$, \\ Xuan Anh Nguyen ${ }^{4}$, Anh Le Hoang ${ }^{5}$, Dac Loc Nguyen ${ }^{4 \dagger}$, Hoang Long Duong ${ }^{3}$, \\ Guenter Engling $^{6 \S}$, Günther Wehrle ${ }^{1}$, Martin Gysel-Beer ${ }^{1}$, Urs Baltensperger ${ }^{1 *}$ \\ ${ }^{1}$ Laboratory of Atmospheric Chemistry, Paul Scherrer Institute, 5232 Villigen PSI, Switzerland \\ ${ }^{2}$ Laboratory for Air Pollution/Environmental Technology, Swiss Federal Laboratories for Materials Science and \\ Technology (Empa), 8600 Dübendorf, Switzerland \\ ${ }^{3}$ Hydro-Meteorological Observation Center (HYMOC), Vietnam Meteorological and Hydrological Administration \\ (VNMHA), Ministry of Natural Resources and Environment (MONRE), Ha Noi, Vietnam \\ ${ }^{4}$ Institute of Geophysics, Vietnam Academy of Science and Technology, Ha Noi, Vietnam \\ ${ }^{5}$ Faculty of Environmental Sciences, VNU University of Science, Vietnam National University, Ha Noi, Vietnam \\ ${ }^{6}$ Department of Biomedical Engineering and Environmental Sciences, National Tsing Hua University, Hsinchu 30013, \\ Taiwan
}

\begin{abstract}
In 2014, Pha Din (1466 m a.s.l.) was established as a Global Atmosphere Watch (GAW) regional station for aerosol and trace gas measurements in northwestern Vietnam. This study presents a five-year climatology of aerosol optical properties derived from nephelometer and aethalometer measurements and a comparison with ground-based remote sensing measurements at the nearby AERONET station Son La. The annual variations of the aerosol measurements at Pha Din are clearly dominated by annually recurring periods with high biomass burning activity in northern Southeast Asia (FebruaryMay). During these periods, the majority of air masses arriving at Pha Din originate from the southwest (northern Thailand, Laos and Myanmar). Both the meteorological conditions and the aerosol optical properties are very similar during the individual high biomass burning periods (increased temperature: $>20^{\circ} \mathrm{C}$; moderate ambient relative humidity: 60-70\%; decreased single scattering albedo: 0.8-0.9; increased absorption Ångström exponent: 1.6-2.0; and scattering Ångström exponent significantly larger than 1). Prior to the biomass burning season (October-January), the meteorological conditions at Pha Din are influenced by the SE Asian monsoon, leading to a frequent transport of air masses from SW China with moderate aerosol loadings. The lowest pollution levels are observed from June to September, which represents the wet season.
\end{abstract}

Keywords: Aerosol optical properties; Biomass burning; Black carbon; Long-term measurements; Global Atmosphere Watch.

\footnotetext{
${ }^{\dagger}$ Now at Joint Mass Spectrometry Centre, Helmholtz Zentrum München - German Research Centre for Environmental Health, Neuherberg, Germany

${ }^{\ddagger}$ Now at Bac Khe 1 Hydro Power Joint stock Company, Vietnam

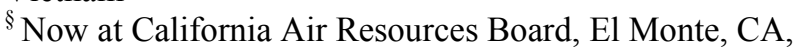
USA

${ }^{\dagger \dagger}$ Now at Atmospheric Sciences, Department of Environmental Sciences, University of Basel, Basel, Switzerland

* Corresponding authors.

E-mail address: nicolas.bukowiecki@unibas.ch; urs.baltensperger@psi.ch
}

\section{INTRODUCTION}

Atmospheric aerosols influence the earth's climate through aerosol-radiation and aerosol-cloud interactions, and they are also known to cause adverse health effects. Light scattering and absorption by atmospheric aerosols influence the solar and terrestrial radiation fluxes, and the change in net radiative flux by anthropogenic aerosol since the preindustrial time contributes to the radiative forcing. Our knowledge of aerosol optical properties such as scattering coefficient, absorption coefficient, single scattering albedo and directional dependence of light scattering, which are needed for radiative transfer calculations for estimating aerosol-radiation interactions (Boucher et al., 2013), still remains incomplete (Jaeglé et al., 2011) due to 
the highly complex and variable characteristics of the atmospheric aerosol.

For a reliable and quantitative prediction of the net radiative forcing by aerosols, obtaining a 4-dimensional coverage of aerosol properties in time and space is crucial (Forster et al., 2007). On a local level, a thorough physical and chemical characterization of the near-ground aerosol is done in the existing international networks, for example, GAW (the Global Atmosphere Watch programme of the World Meteorological Organization), ACTRIS (the European Research Infrastructure for the observation of Aerosol, Clouds, and Trace Gases) or the NOAA (National Oceanic and Atmospheric Administration) Federated Aerosol Network, which all aim at providing harmonized data from stations around the globe (Andrews et al., 2011; Collaud Coen et al., 2013). In AERONET (Aerosol Robotic Network), EARLINET (the European Aerosol Research Lidar Network, now incorporated in ACTRIS) and other networks, vertically resolved measurements using lidars and column integrated measurements using sun photometers allow for the retrieval of relevant aerosol optical properties in the air column above ground for further comparison with satellite based aerosol products (Holben et al., 1998; Bösendorfer et al., 2001). Although both in-situ measurements and columnar measurements provide valuable stand-alone information about the composition and dynamics of the troposphere, only interlinking all measurement types at the same site and filling the regional gaps in the global measurement network will provide the full information that is crucially required by climate system models to assess the aerosol climate effects on all spatial scales (Lopatin et al., 2013; Kaskaoutis et al., 2014; Mann et al., 2014; Samset et al., 2014; Sarkar et al., 2018).

Northern Southeast Asia is an area that is well-known for being severely affected by intense seasonal biomass burning (BB) in the form of forest wildfires and agricultural crop burning as well as biofuel usage for cooking (Carmichael et al., 2003; Streets et al., 2003, 2009; Gautam et al., 2013). Myanmar, Thailand and Laos have been identified as source regions for BB in many existing studies (Yen et al., 2013; Krishna Prasad et al., 2015; Duc et al., 2016; Loftus et al., 2016; Pantina et al., 2016; Li et al., 2017; Lin et al., 2017). These show that in the northern part of Southeast Asia $\left(15-25^{\circ} \mathrm{N}, 90-120^{\circ} \mathrm{E}\right)$, atmospheric mean flow patterns largely control the transport and dispersion of BB plumes. In the lower mid-troposphere (700-850 hPa), the streamlines are mostly southwesterly from February to April due to the dominating winter tropical SE Asian high (located south of $20^{\circ} \mathrm{N}$ over the region of the northern East China Sea or South China Sea in March). This is associated with an uplift of pollutants emitted by BB to a pressure level of approx. $700 \mathrm{hPa}$ (corresponding to roughly $3000 \mathrm{~m}$ a.s.l.) by an upward branch of the local east-west cell/circulation (Lin et al., 2013). In the boundary layer $(925-850 \mathrm{hPa})$, the streamlines are mostly southwesterly/southerly/southeasterly due to the presence of mountain ranges located on the eastern and western coasts of the SE Asian peninsula and of the vast plain in the central peninsula (Chen et al., 2002; Lin et al., 2013). During the rest of the year, the meteorology in the northern SE Asian region is dominated by the NE monsoon (October-January), with frequent air mass transport from SW China (Lin et al., 2017), as well as by the SE monsoon (June-September) associated with frequent rainfall and high relative humidity.

In 2014, the GAW regional station Pha Din (PDI) was established in northwestern Vietnam at a rural background site in a mountainous area at $1463 \mathrm{~m}$ a.s.l., providing continuous measurements of ground-based in-situ aerosol parameters (aerosol absorption coefficient and aerosol scattering coefficient) and trace gases $\left(\mathrm{CO}_{2}, \mathrm{CH}_{4}, \mathrm{CO}\right.$ and $\mathrm{O}_{3}$ ). The measurements at Pha Din are the first continuous aerosol monitoring activities in northern Vietnam and the entire surrounding region. The goal of this paper is to show the importance of the continuous monitoring at Pha Din for the long-term assessment of $\mathrm{BB}$ in the northern SE Asian area. BB and traffic source regions will be identified using air mass backward-trajectories, and the Pha Din data will be compared with other aerosol measurements that have been conducted in northern Vietnam in recent years on a non-continuous basis.

\section{METHODS}

\section{Location}

Pha Din, located in the northwest of Vietnam (see Fig. 1), is a mountain pass at the border of the Son La and Dien Bien provinces. The pass is embedded in a mountain chain with hills between 700 and $1600 \mathrm{~m}$ a.s.l., stretching from China into Vietnam in a northwest-to-southwest orientation. The Pha Din measuring site (GAW station acronym: PDI) is located on a hilltop close to the pass at $1466 \mathrm{~m}$ a.s.l. $\left(21.573^{\circ} \mathrm{N}, 103.516^{\circ} \mathrm{E}\right)$ covered with forest. The station itself is above the canopy. It was established in 1962 as a meteorological station of the Viet Nam Meteorological and Hydrological Administration (VNMHA) and started providing official data in 1964. In February 2014, PDI was upgraded with continuous aerosol and trace gas measurements within the framework of the Capacity Building and Twinning for Climate Observing Systems (CATCOS) project (SDC, 2018), and the operation and data management was handed over to VNMHA in 2017 under Decision No. 29/QD-BTNMT of the Vietnamese Ministry of Natural Resources and Environment. There are no residents at the station except for the custodians, no relevant residential areas within 10-20 km except for sparse individual farmhouses, and no coal-fired power plants or other industrial activities in the region. The area is under the surveillance of the government; therefore, there is a low probability for extensive growth of residential or industrial activities around the station.

\section{Inlet System}

The aerosol measurements at Pha Din follow the GAW recommendations for aerosol sampling (WMO/GAW, 2016). The site was audited by the GAW World Calibration Centre for Aerosol Physics (WCCAP) in 2016. Results are available in an openly accessible audit report (WCCAP, 2016). The inlet is a custom made total suspended particulate matter 

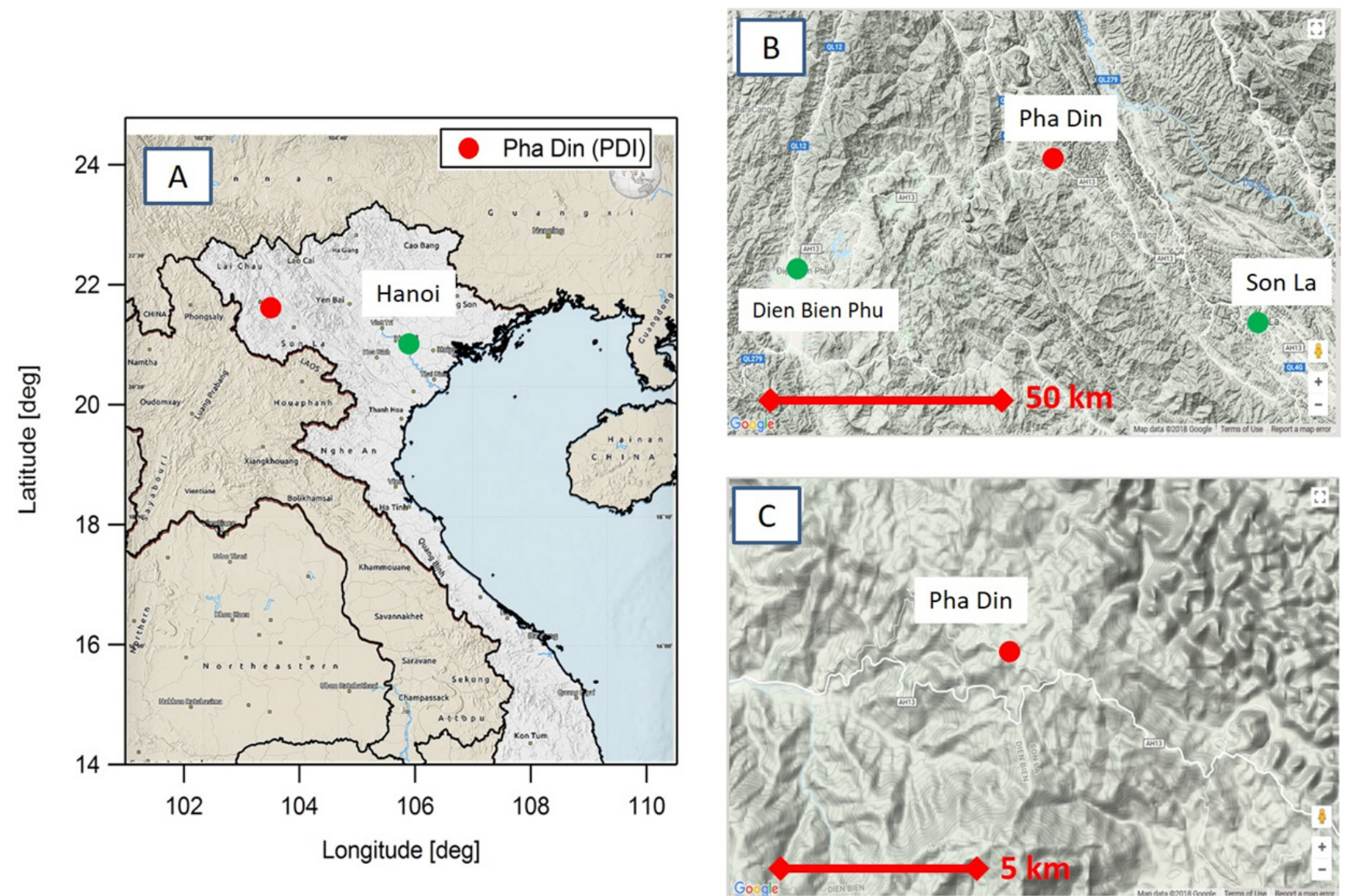

Fig. 1. Geographical location of the sampling site (Images: Google Maps, Maphill), in three different zoom levels (A, B, and $\mathrm{C}$ ).

(TSP) inlet, as recommended for stations that are frequently in clouds. In accordance with GAW guidelines, the sampling air was dried with dried, particle-free dilution air to maintain/achieve a relative humidity $(\mathrm{RH})$ below $40 \%$ inside the instruments. During the period of measurement, the RH was $15-40 \%$ with a functioning dilution system (see Fig. S1 in the Supplementary Information). Periods with a malfunctioning dilution system were flagged accordingly. The measured ambient aerosol light absorption and scattering data were corrected by the effective dilution factor (set to be around 2) and are reported for standard temperature and pressure (STP) conditions (1013 mbar and $0^{\circ} \mathrm{C}$ ) in this study.

\section{Aerosol Light Absorption and BC Source Apportionment}

The aerosol absorption coefficient $\left(b_{\text {abs }}\right)$ was determined from aethalometer measurements (Model AE31; Magee Scientific Inc.) at 7 wavelengths $(370,470,520,590,660$, 880 and $950 \mathrm{~nm}$ ), with a native time resolution of 5 minutes. The aethalometer raw data processing followed the current GAW/ACTRIS recommendations (Liousse et al., 1993; Petzold et al., 1997; Weingartner et al., 2003; Collaud Coen et al., 2010; Park et al., 2010; Bond et al., 2013; Drinovec et al., 2015; WMO/GAW, 2016; Zanatta et al., 2016) and includes compensation for non-linear filter loading effects and correction for multi-scattering effects (Weingartner et al.,
2003) which are described in detail in the Supplementary Information of this article. The correction for multiscattering effects is achieved using a specific $C$-value (Zotter et al., 2017). Lacking simultaneous measurements with an absorption reference method, a constant and wavelength independent $C$-value of 3.5 was applied in this study, following the GAW recommendations (WMO/GAW, 2016; Zanatta et al., 2016), to infer the absorption coefficients $\left(b_{\text {abs }}\right)$ from the loading compensated attenuation coefficients measured by the aethalometer.

The spectral dependence of light absorption can be used to apportion aerosol light absorption and particulate BC mass to biomass burning and traffic emissions, if these are the only sources contributing to light absorbing aerosol (Kirchstetter et al., 2004; Sandradewi et al., 2008). We applied this "aethalometer model" approach to the absorption coefficients $\left(b_{\text {abs }}\right)$ measured at the wavelengths 470 and $950 \mathrm{~nm}$ using the following equations (Sandradewi et al., 2008; Zotter et al., 2017):

$$
b_{a b s, B B}(950 \mathrm{~nm})=\frac{b_{a b s}(470 \mathrm{~nm})-b_{a b s}(950 \mathrm{~nm}) \cdot\left(\frac{470}{950}\right)^{-\alpha_{T R}}}{\left(\frac{470}{950}\right)^{-\alpha_{B B}}-\left(\frac{470}{950}\right)^{-\alpha_{T R}}}
$$




$$
b_{a b s, T R}(950 \mathrm{~nm})=\frac{b_{a b s}(470 \mathrm{~nm})-b_{a b s}(950 \mathrm{~nm}) \cdot\left(\frac{470}{950}\right)^{-\alpha_{B B}}}{\left(\frac{470}{950}\right)^{-\alpha_{T R}}-\left(\frac{470}{950}\right)^{-\alpha_{B B}}}
$$

where $\alpha$ is the absorption Ångström exponent. BB and TR denote the sources "biomass burning" and "traffic" to be apportioned. The aethalometer model is based on the fact that typical traffic emissions contain $\mathrm{BC}$ as the exclusive light absorbing species, whereas biomass burning emissions contain co-emitted brown carbon, which results in a higher $\alpha$. A recent study (Zotter et al., 2017) referenced the aethalometer model against ${ }^{14} \mathrm{C}$-based source apportionment and found optimum $\alpha$-values of $\alpha_{T R}=0.9$ and $\alpha_{B B}=1.68$ for the above wavelength pair. However, this $\alpha_{B B}$ is specific to wintertime Switzerland, where wood burning for domestic heating is the dominant biomass burning source. The spectral dependence of the typical biomass burning aerosol at Pha Din, which originates from wildfires, agricultural crop burning and the use of biofuel for cooking, may be different. Indeed, the $\alpha$-values of the whole aerosol were as high as $\sim 2$ when biomass burning influence dominated, thereby clearly exceeding $\alpha_{B B}=1.68$. Applying $\alpha_{B B}=1.68$ in the aethalometer model would consequently result in negative traffic contribution. Therefore, we chose $\alpha_{B B}=1.8$ instead. The uncertainty of $\alpha_{B B}$ will be shown and discussed in the context of Fig. 4 later in this article. The respective contributions of biomass burning and traffic to the equivalent black carbon mass concentrations $\left(m_{\mathrm{eBC}}\right)$ were then calculated as:

$$
\begin{aligned}
& m_{\mathrm{eBC}, \mathrm{TR}}=\frac{b_{a b s, T R}(950 \mathrm{~nm})}{\operatorname{MAC}_{\mathrm{TR}}(950 \mathrm{~nm})} \\
& m_{\mathrm{eBC}, \mathrm{BB}}=\frac{b_{a b s, B B}(950 \mathrm{~nm})}{\operatorname{MAC}_{\mathrm{BB}}(950 \mathrm{~nm})}
\end{aligned}
$$

where $\mathrm{MAC}_{\mathrm{TR}}(950 \mathrm{~nm})$ and $\mathrm{MAC}_{\mathrm{BB}}(950 \mathrm{~nm})$ are the mass absorption cross sections for traffic and biomass burning, respectively, and were assumed to be $6.6 \mathrm{~m}^{2} \mathrm{~g}^{-1}$. This value translates to a MAC of around $10 \mathrm{~m}^{2} \mathrm{~g}^{-1}$ at 630 $\mathrm{nm}$, which is a typical value for internally mixed BC at rural and remote sites (Zanatta et al., 2016).

\section{Aerosol Light Scattering}

Aerosol total light scattering coefficients $\left(b_{\text {scat }}\right)$ and hemispheric backwards scattering coefficients were measured using an integrating nephelometer (Aurora 3000, Ecotech Inc.) at 3 wavelengths $(450,525$ and $635 \mathrm{~nm})$ with a native time resolution of $1 \mathrm{~min}$. Data were corrected for the truncation error of the angle non-ideality (Müller et al., 2011). Zero-offset correction was performed at a daily interval, and the calibration span value was regularly defined and verified using $\mathrm{CO}_{2}$ as reference gas.

\section{Aerosol Optical Properties}

Using the aethalometer and nephelometer data, the following aerosol optical properties can be retrieved:

$$
b_{\text {ext }}(\lambda)=b_{\text {scat }}(\lambda)+b_{a b s}(\lambda)
$$

$$
\begin{aligned}
& S S A_{\text {dry }}(\lambda)=\frac{b_{\text {scat }}(\lambda)}{b_{\text {ext }}(\lambda)} \\
& S S A_{\text {ambient }}(\lambda, \mathrm{RH})=\frac{b_{\text {scat }}(\lambda) \cdot f(\mathrm{RH}, \lambda)}{b_{\text {scat }}(\lambda) \cdot f(\mathrm{RH}, \lambda)+b_{\text {abs }}(\lambda)}
\end{aligned}
$$

$$
\frac{b_{a b s}\left(\lambda_{1}\right)}{b_{a b s}\left(\lambda_{2}\right)}=\left(\frac{\lambda_{1}}{\lambda_{2}}\right)^{-A A E}
$$

$$
\frac{b_{\text {scat }}\left(\lambda_{1}\right)}{b_{\text {scat }}\left(\lambda_{2}\right)}=\left(\frac{\lambda_{1}}{\lambda_{2}}\right)^{-S A E}
$$

$$
\frac{b_{e x t}\left(\lambda_{1}\right)}{b_{e x t}\left(\lambda_{2}\right)}=\left(\frac{\lambda_{1}}{\lambda_{2}}\right)^{-E A E}
$$

where $b_{\text {ext }}(\lambda)$ is the aerosol extinction coefficient and $S S A_{d r y}(\lambda)$ is the dry single scattering albedo (at laboratory conditions with $\mathrm{RH}<40 \%)$. $S S A_{\text {ambient }}(\lambda)$ is the single scattering albedo at ambient $\mathrm{RH}$, determined using the scattering enhancement factor $f(\mathrm{RH}, \lambda)$ obtained by external methods (Zieger et al., 2015). $f(\mathrm{RH})$ is the key parameter for describing the $\mathrm{RH}$ dependence of the particle light scattering coefficient $b_{\text {scat }}$ and is defined as the ratio of the ambient $b_{\text {scat }}\left(\mathrm{RH}_{\mathrm{amb}}\right)$ to its dry value $b_{\text {scat }}\left(\mathrm{RH}_{\text {dry }}\right)$. Knowledge of this $\mathrm{RH}$ effect is of crucial importance to climate forcing calculations but is also needed for the validation or comparison of remote sensing with in-situ measurements, as it will be performed in the section "Comparison with AERONET data".

AAE (also called $\alpha$ ) is the absorption Ångström exponent; SAE, the scattering Ångström exponent and EAE, the extinction Ångström exponent. Because $f(\mathrm{RH})$ is also wavelength dependent (Zieger et al., 2015; Skupin et al., 2016), EAE, SAE and AAE also exhibit a dependence on RH. The reported values will be labelled as "dry" or "ambient" throughout this manuscript, reflecting the different measurement approaches (ground based in-situ vs. column-based). Typical values will be discussed in the respective context in "Results and Discussion".

\section{Meteorological Measurements}

The PDI station has the function to monitor the meteorological parameters according to the technical requirements of the Vietnamese National Technical Regulation on Meteorological Observations (MONRE, 2012). Wind speed, wind direction, $\mathrm{RH}$ and temperature are recorded four times a day, while precipitation is measured as daily bulk samples. The readings of the 6-hour interval data are taken at 00:00, 06:00, 12:00 and 18:00 UTC, corresponding to $07: 00,13: 00,19: 00$ and 01:00 local time. 
Additionally, ambient sensors for temperature and $\mathrm{RH}$ recording data with 1 min time resolution are mounted at the main inlet for the aerosol and gas phase measurements.

\section{Carbon Monoxide Measurements}

Carbon monoxide (CO) was measured with a cavity ring-down spectrometer (CRDS) (Picarro Inc., G2401) which allows the simultaneous detection of $\mathrm{CO}$, carbon dioxide and methane. The CRDS has been shown to be a suitable technique providing high-precision $\mathrm{CO}$ observations in ambient air (Zellweger et al., 2012; Yver Kwok et al., 2015). The robustness and little required maintenance of these analyzers also allow long-term observations at remote locations (Fang et al., 2016). All data are corrected for dilution and pressure broadening effects due to humidity and thus represent dry air mole fractions. Samples from four calibration tanks are measured every 3 to 6 days. $\mathrm{CO}$ concentrations in the calibration tanks were all directly traced back to the GAW Central Calibration Laboratory for CO at NOAA. Data are reported on the WMO CO X2004 scale. Samples from an additional target cylinder were measured every 25 hours for quality control.

\section{AERONET}

For comparison to the ground based in-situ measurements at Pha Din, AERONET sun photometer data (CE318 multi-band sun photometer; Cimel Electronique) collected at the nearby site Son La (see Fig. 1) are used in this study. The Son La AERONET site $\left(21^{\circ} 19^{\prime} 55^{\prime \prime} \mathrm{N}, 103^{\circ} 54^{\prime} 18^{\prime \prime} \mathrm{E}\right.$; $675 \mathrm{~m}$ a.s.1.) is located approximately $48 \mathrm{~km}$ SE of Pha Din (Wang et al., 2015). The site is located on a hill in Son La City (population: 98,751) and surrounded by grass and tree vegetation. In contrast to Pha Din as a remote site, the Son La site is not only influenced by BB emissions (Nguyen et al., 2016; Popovicheva et al., 2016) but is also directly influenced by the anthropogenic emission sources of the city. The AERONET photometers measure the spectral direct-beam solar radiation as well as directional diffuse radiation along the solar almucantar (Holben et al., 1998). In addition to measuring direct solar irradiance, they also measure the sky radiance at four wavelengths $(440,675$, 870 and $1020 \mathrm{~nm}$ ) along the solar almucantar. The solar zenith angles are restricted to $>50^{\circ}$ (i.e., in early morning and late afternoon). The sky radiance measurements are used to retrieve additional columnar aerosol properties, including the volume size distribution, phase function, real and imaginary components of the refractive index, particle effective radius, single-scattering albedo and the asymmetry factor, which are typically computed using AERONET inversion algorithms (Dubovik and King, 2000; Dubovik et al., 2006; Holben et al., 2006). The uncertainty in the retrieved single scattering albedo is estimated to be \pm 0.03 . In addition, for absorption related inversion products, the Level 2.0 direct sun $\mathrm{AOD}_{440}$ must be greater than 0.4. AERONET inversion products are quality assured based on literature (Dubovik et al., 2000; Holben et al., 2006). The AERONET data from Son La were downloaded from the AERONET website (AERONET, 2018), as Version 3, Level 2 (cloud screened and quality-assured). For Son La, the available AERONET data consisted of 400 individual measurements, distributed over 124 days in 2014-2017, mostly in March (167 measurements), April (80 measurements) and May (60 measurements).

\section{Levoglucosan as Biomass Burning Marker}

Vegetative biomass burning emits gases and particles into the atmosphere and has been described as an important source of organic aerosols (Simoneit and Elias, 2001). Levoglucosan and mannosan, produced by pyrolysis of cellulose and hemicellulose, respectively, are well-established tracers for BB (Simoneit et al., 1999; Simoneit, 2002). During a field campaign with an intensive BB period from 22 March to 12 April 2015, $\mathrm{PM}_{2.5}$ (particulate matter with an aerodynamic cut-off diameter $\leq 2.5 \mu \mathrm{m}$ ) was collected on quartz fiber filters (47 mm diameter, 2500QAT-UP; PALL Life Sciences, Inc., USA) by MiniVol $^{\mathrm{TM}}$ TAS samplers (Airmetrics, USA) with a 24-h sampling protocol. The quartz fiber filters were extracted ultrasonically with deionized distilled water and filtered through Teflon syringe filters ( $0.45 \mu \mathrm{m}$ pore size; Millipore Corp., Billerica, USA). The extract solutions were then analyzed by high performance anion exchange chromatography with pulsed amperometric detection (HPAEC-PAD) for the quantitative determination of various carbohydrates, including levoglucosan and mannosan. The technical details of the analysis method have been reported previously (Engling et al., 2006; Zhang et al., 2013).

\section{FLEXTRA Backward Trajectories}

The FLEXTRA backward-trajectory model (Stohl et al., 1995; Stohl and Seibert, 1998) was used to trace the origin of the air masses arriving at Pha Din. Kinematic backward trajectories were calculated on operational 3-hour ECMWF analysis/forecast fields $\left(1^{\circ} \times 1^{\circ}\right.$ horizontal resolution and 137 vertical levels). For the whole observation period, trajectories were initialized every 4 hours at different heights above the site and were followed 10 days backward in time. For the analysis presented below, an initial height for the trajectories of $420 \mathrm{~m}$ above ground was selected, which roughly represents the middle between the real station altitude and the altitude of the smoothed model topography.

\section{AVHRR Land Fire Hotspots}

The monthly sum of satellite detected land fire hotspots for Vietnam and the surrounding countries were downloaded from the website of the ASEAN Specialised Meteorological Centre (ASMC, 2018). The hotspots published by ASMC are observed using the NOAA satellite Advanced Very High Resolution Radiometer (AVHRR) sensor. Hotspots may be undetected due to cloudy conditions or partial satellite pass. Hotspot counts from 2016 onwards are based on the NOAA-19 satellite, while for the period of 20062015, they are based on the NOAA-18 satellite. Depending on the size and proximity of fires, they may or may not appear as separate hotspots. If the total size of a detected fire is smaller than a pixel, the fire will appear as a single hotspot. As for active fires larger than a pixel, they will appear as multiple hotspots. 


\section{RESULTS AND DISCUSSION}

\section{Annual Variation of Aerosol Optical Properties and their Relation to Biomass Burning}

Fig. 2 shows the time series for the aerosol absorption coefficient $\left(b_{\mathrm{abs}}\right)$, the total aerosol scattering coefficient $\left(b_{\text {scat }}\right)$, the dry absorption Ångström exponent $\left(\mathrm{AAE}_{\text {dry }}\right)$, carbon monoxide and the monthly land fire hotspot sum for Vietnam and the surrounding countries, for the entire period of the continuous measurements (February 2014-June 2018). High $b_{\text {abs }}$ values clearly correlate with high carbon monoxide (CO) mixing ratio and high number of land fire hotspots for Vietnam and the surrounding countries, with distinct maxima between February and May. BB is known to be a major source of CO (van der Werf et al., 2006; Duncan et al., 2007; Schultz et al., 2008). Due to its atmospheric lifetime on the order of weeks to months (Holloway et al., 2000), CO is a suitable tracer for BB. In regions such as Southeast Asia, the systematic variation in BB intensity throughout the year results in pronounced seasonal cycles of CO emissions (Arellano et al., 2006), which are also reflected in the atmospheric $\mathrm{CO}$ levels at Pha Din. The periods with the highest $\mathrm{BB}$ influence at Pha Din are consistently characterized by no rainfall, reduced $\mathrm{RH}$ and increased temperature, as well as $\mathrm{AAE}_{\mathrm{dry}}$ values higher than 1.4, peaking up to 1.9-2 (see also Figs. S2-S10 in the
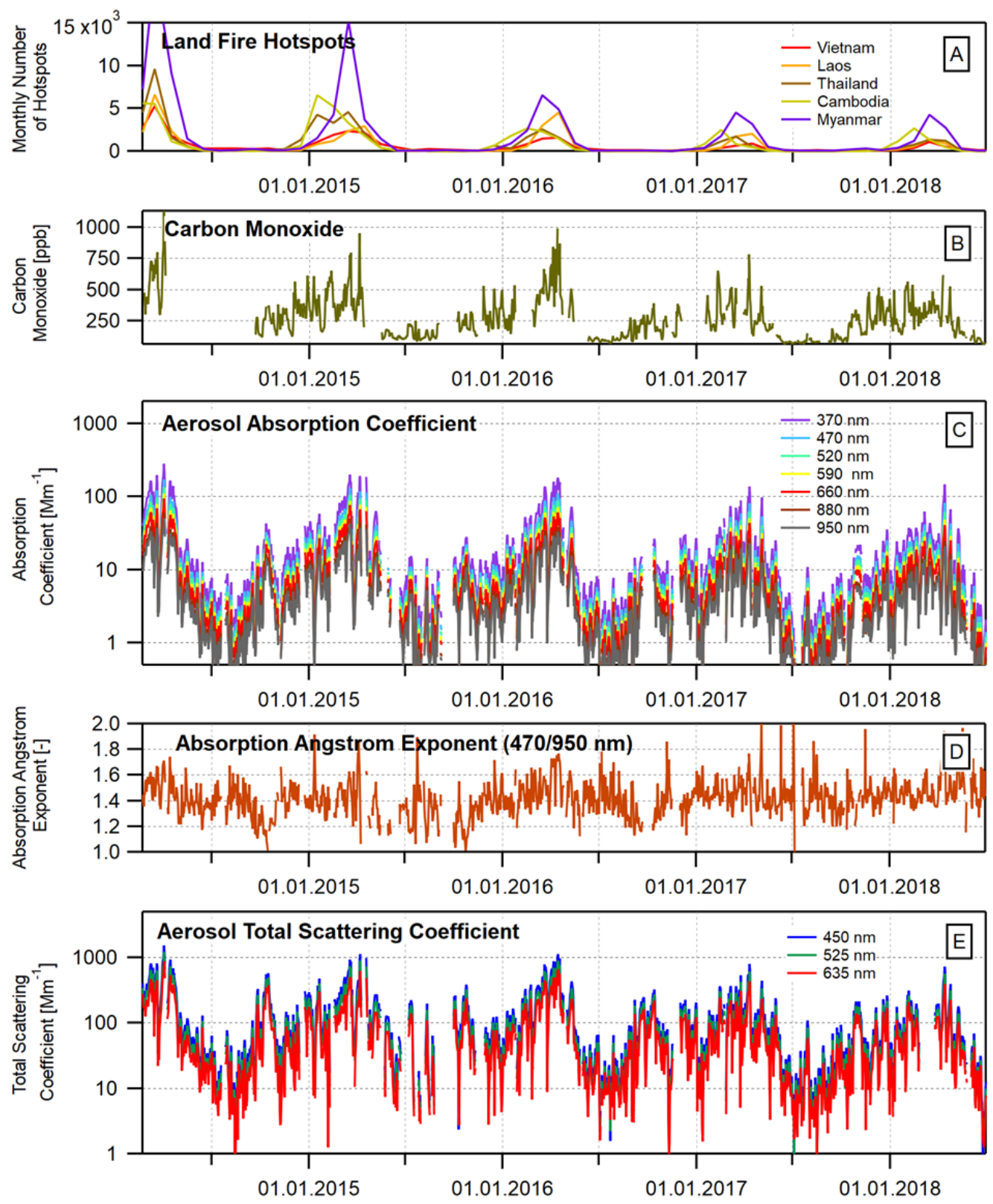

Fig. 2. Time series 2014-2018 of (A) the monthly sum of satellite detected land fire hotspots for Vietnam, Laos, Thailand, Cambodia and Myanmar, (B) the carbon monoxide mixing ratio (daily average values), (C) the aerosol absorption coefficient (daily average values), (D) the absorption Angstrom exponent (daily average values, derived from the aerosol absorption coefficients at $470 \mathrm{~nm}$ and $950 \mathrm{~nm}$ ) and (E) the aerosol total scattering coefficient (daily average values). 
Supplementary Information). In contrast, the lower values in the summer months largely coincide with the SE Asian summer monsoon with more rain and generally more humid conditions. During the time period covered so far by the measurements at Pha Din, a decrease in peak intensity for all parameters is observed between 2014 and 2018 .

Fig. 3 shows a classification of aerosol types based on AAE and SAE (Cazorla et al., 2013). AAE dry $_{\text {reaches 1.6- }}$ 2.0 during $\mathrm{BB}$ periods, a typical value for $\mathrm{BB}$ dominated aerosol in northern Indochina (Wang et al., 2015). SAE $\mathrm{S}_{\text {dry }}$ is $>1.5$, pointing to a dominant contribution of accumulation mode particles to light scattering, as is expected for BB aerosols, and does not indicate a significant influence of coarse mode dust. According to the classification used in Fig. 3, the aerosol detected during high $\mathrm{BB}$ episodes is thus characterized as "OC dominated", while for the rest of the year, the major fraction of the data is classified as "EC/OC mixture".

The aethalometer model (see "Methods") allows for splitting the $\mathrm{eBC}$ mass concentration into its traffic and $\mathrm{BB}$ fractions as shown in Fig. 4 (daily and monthly mass concentrations and monthly fractions). The aethalometer model clearly attributes a major part of the eBC mass concentration to $\mathrm{BB}$ during the time periods with maximal aerosol absorption coefficients $(\sim 80 \%$; see top panel in Fig. 4), while the contributions of $\mathrm{eBC}(\mathrm{TR})$ and $\mathrm{eBC}(\mathrm{BB})$ are similar during the rest of the year, with higher absolute values during the dry season and lower values during the wet season. Traffic is even a slightly more dominant source than $\mathrm{BB}$ during the wet season.

\section{Origin of Air Masses at Pha Din}

The origin of the air masses arriving at Pha Din was assessed with the help of FLEXTRA backward trajectories (hereafter called "back-trajectories"). Based on the wellknown seasonal meteorology patterns in northern SE Asia (see "Introduction"), the trajectory analysis was performed for the three dominating meteorological regimes, namely (a) the SE monsoon ("wet season", June-September), (b) the NE monsoon (October-January) and (c) the winter/spring SE Asian tropical high (February-May). For these three regimes, the aerosol optical properties as well as meteorological parameters were apportioned to specific grid cells on a world map, following existing approaches described in the literature (Zieger et al., 2015; Franke et al., 2017). The 3-day FLEXTRA back-trajectories were mapped onto a grid with a horizontal resolution of $0.5^{\circ} \times 0.5^{\circ}$. For each trajectory in an individual grid cell, the aerosol/meteorological parameter measured at Pha Din at the time of the trajectory arrival is assigned to the cell, and the average of all values assigned to a grid cell is formed. This method provides qualitative information on how much of a given quantity is (on average) observed at the receptor station after the air mass has crossed a certain grid cell. The method has clear limitations (Franke et al., 2017) and does not replace an indepth particle dispersion analysis, but it represents a simple way to qualitatively identify source regions for a parameter measured at the receptor site.

In the main BB season (Fig. 5), the trajectory density plot (Fig. 5(A)) shows two equally dominant branches, one with back-trajectories covering the area SW of Pha Din (Laos, northern Thailand, Cambodia and Myanmar) and a second one covering the NE sector (northern Vietnam and southwestern China). The average trajectory altitude above model ground (Fig. 5(B)) is lower than 300-600 meters for a large part of the area, indicating that the $\mathrm{BB}$ influenced

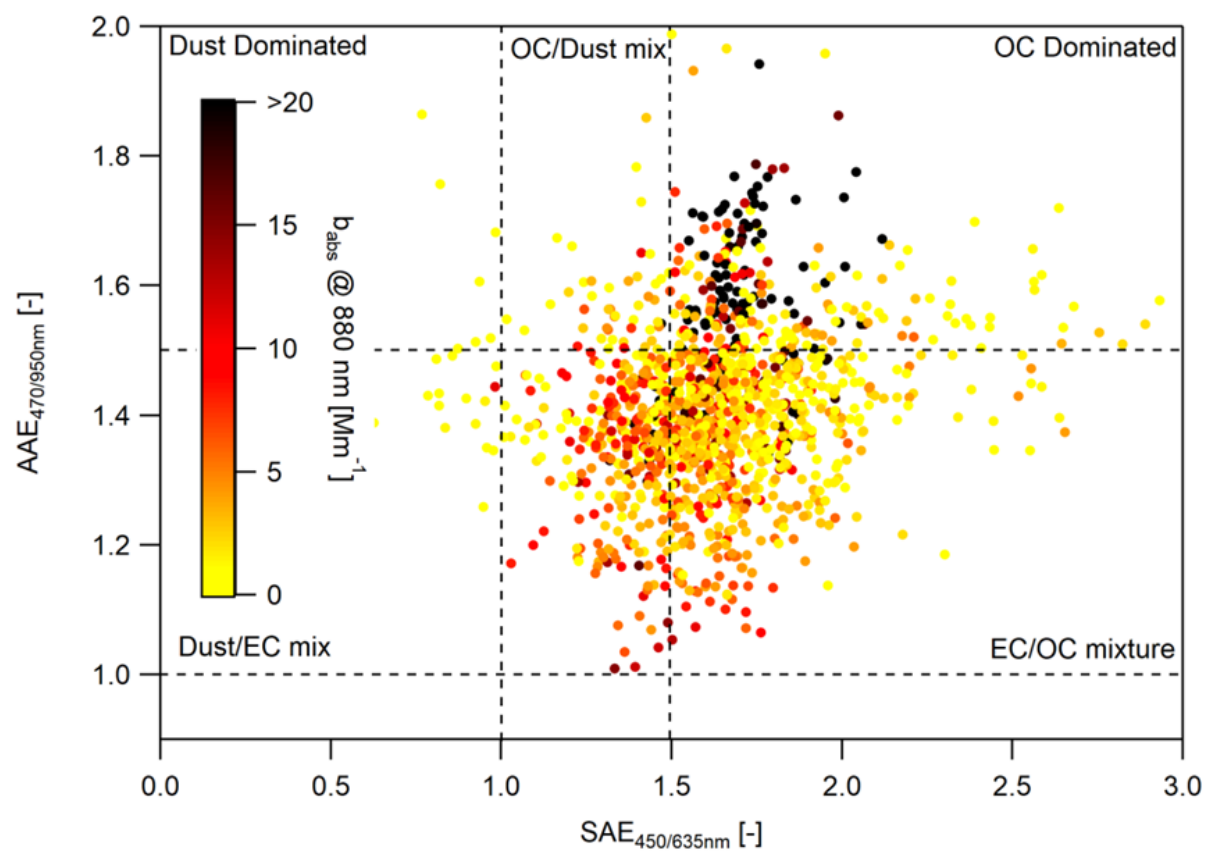

Fig. 3. Absorption Angstrom exponent (AAE, 470/950 nm) versus scattering Angstrom exponent (SAE, 450/635 nm), color coded by the aerosol absorption coefficient at $880 \mathrm{~nm}$. Dry daily average values are shown (February 2014-June 2018). The classification by aerosol type is based on Cazorla et al. (2013). 

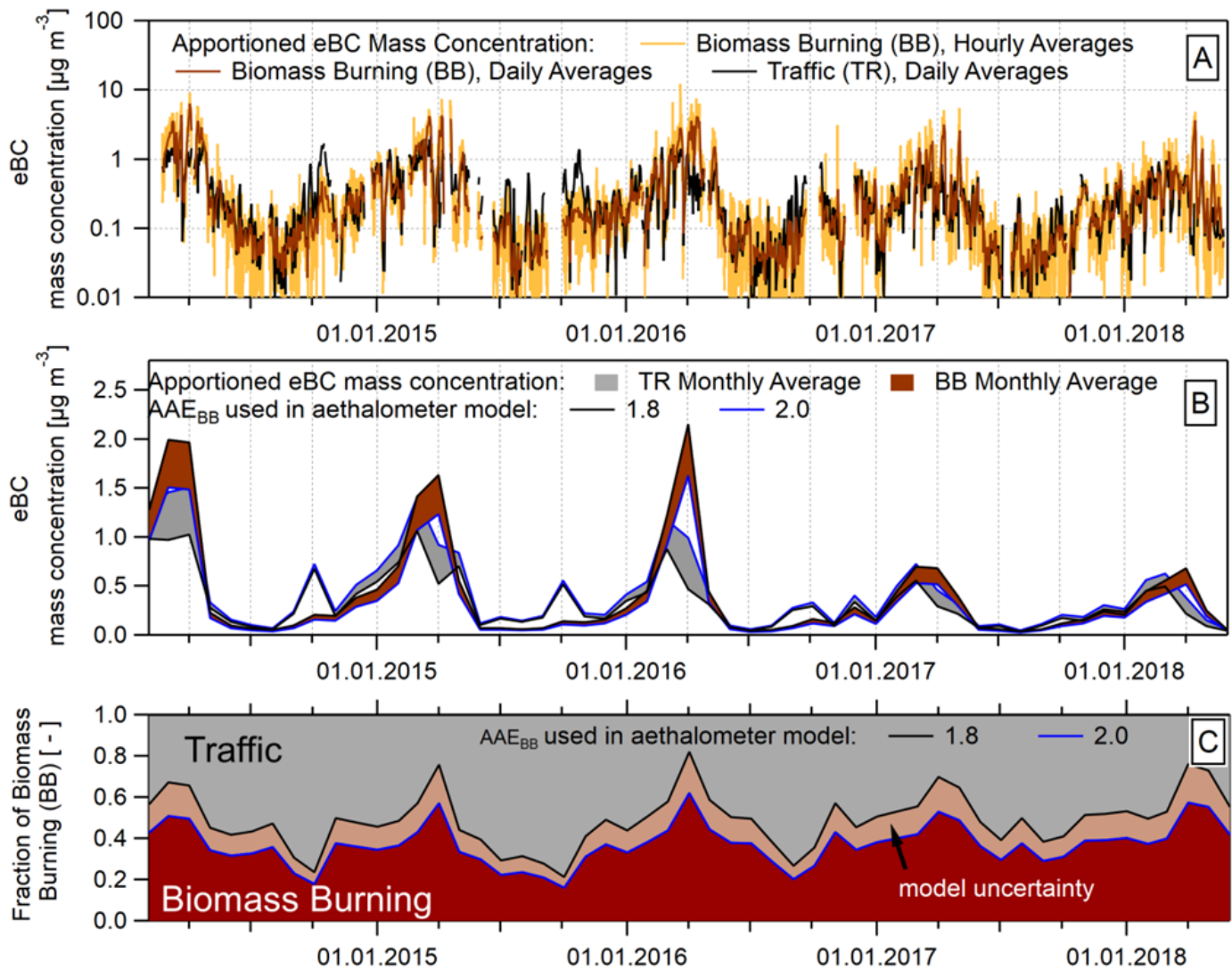

Fig. 4. (A) Equivalent black carbon (eBC) mass concentrations (daily/hourly values) from biomass burning (BB) and traffic (TR) at Pha Din, using the aethalometer based approach by Zotter et al. (2017), (B) Same with monthly average values and $(\mathrm{C})$ Corresponding $\mathrm{BB}$ and $\mathrm{TR}$ fractions (monthly average values).

air masses arriving at Pha Din had sufficient contact with the $\mathrm{BB}$ aerosols emitted on the ground. The source region for eBC(BB) mass (Fig. 5(C)) is clearly located in the SW sector and fully matches the previously identified BB source regions (Laos, northern Thailand, Cambodia and Myanmar; see "Introduction"). The identified source region is furthermore associated with increased temperature $\left(>20^{\circ} \mathrm{C}\right)$ and rather low relative humidity $(<60 \%$; Fig. $5(\mathrm{E}))$. The source region for eBC(TR) mass (Fig. $5(\mathrm{C})$ ) is more diffuse, with some isolated hotspots in the SE sector along the coastal areas of Thailand and Vietnam. During a field campaign at Pha Din from late March to early April in 2015, molecular BB markers (levoglucosan and mannosan) were measured on additionally collected $\mathrm{PM}_{2.5}$ filters (see "Methods") during a BB intensive period with air masses advected from the SW. Levoglucosan and mannosan concentrations averaged at $473 \pm 635(2-2285) \mathrm{ng} \mathrm{m}^{-3}$ and $58 \pm 33(16-137) \mathrm{ng} \mathrm{m}^{-3}$, respectively, indicating a significant impact of $\mathrm{BB}$ on the ambient aerosol. Fig. 6 shows that the apportioned $\mathrm{eBC}(\mathrm{BB})$ mass concentrations correlate very well with the levoglucosan/mannosan measurements. The distinctly high levoglucosan concentrations (exceeding those reported at many other sites across the globe; Simoneit, 2002) along with the eBC(BB) pattern clearly demonstrate the strong biomass-burning impact on air quality in this region. The fact that the aethalometer model apportions the peak concentrations to $\mathrm{BB}$ further confirms the validity of the apportionment approach.

For the warm and humid summer wet season (Fig. S11, Supplementary Information), no spatially relevant source regions are identified, with the exception of small hotspots along the Chinese sea (eBC(BB) mass) and SW Chinese mainland (eBC(TR) mass). During the NE monsoon in the colder and humid winter months (Fig. S12, Supplementary Information), a relatively large source region for both eBC(BB) and eBC(TR) mass is found over mainland SW China. For this period of the year, a previous study (Co et $a l ., 2014)$ reported that BB plumes from the NE were also reaching Tam Dao, a rural mountain site in northern Vietnam $200 \mathrm{~km}$ ESE of Pha Din.

\section{Comparison with AERONET Data}

The cloud-free conditions at Pha Din during BB plumes from the SW also coincide with a generally low $\mathrm{RH}(<50 \%)$. This provides an excellent opportunity to intercompare ground-based in situ measurements with column-based in-situ measurements under dry conditions. The semicontinuous AERONET measurements performed at Son La, approximately $50 \mathrm{~km}$ from Pha Din at $675 \mathrm{~m}$ a.s.l. (see Fig. 1), allow for an intercomparison with the continuously measured in-situ aerosol optical properties. Fig. 7(A) shows the in-situ $\mathrm{EAE}_{\text {dry }}$, in-situ $\mathrm{AAE}_{\text {dry }}$, AERONET EAE

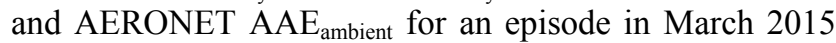
with high $\mathrm{BB}$ and available AERONET data. 


\section{October to January (NE Monsoon)}
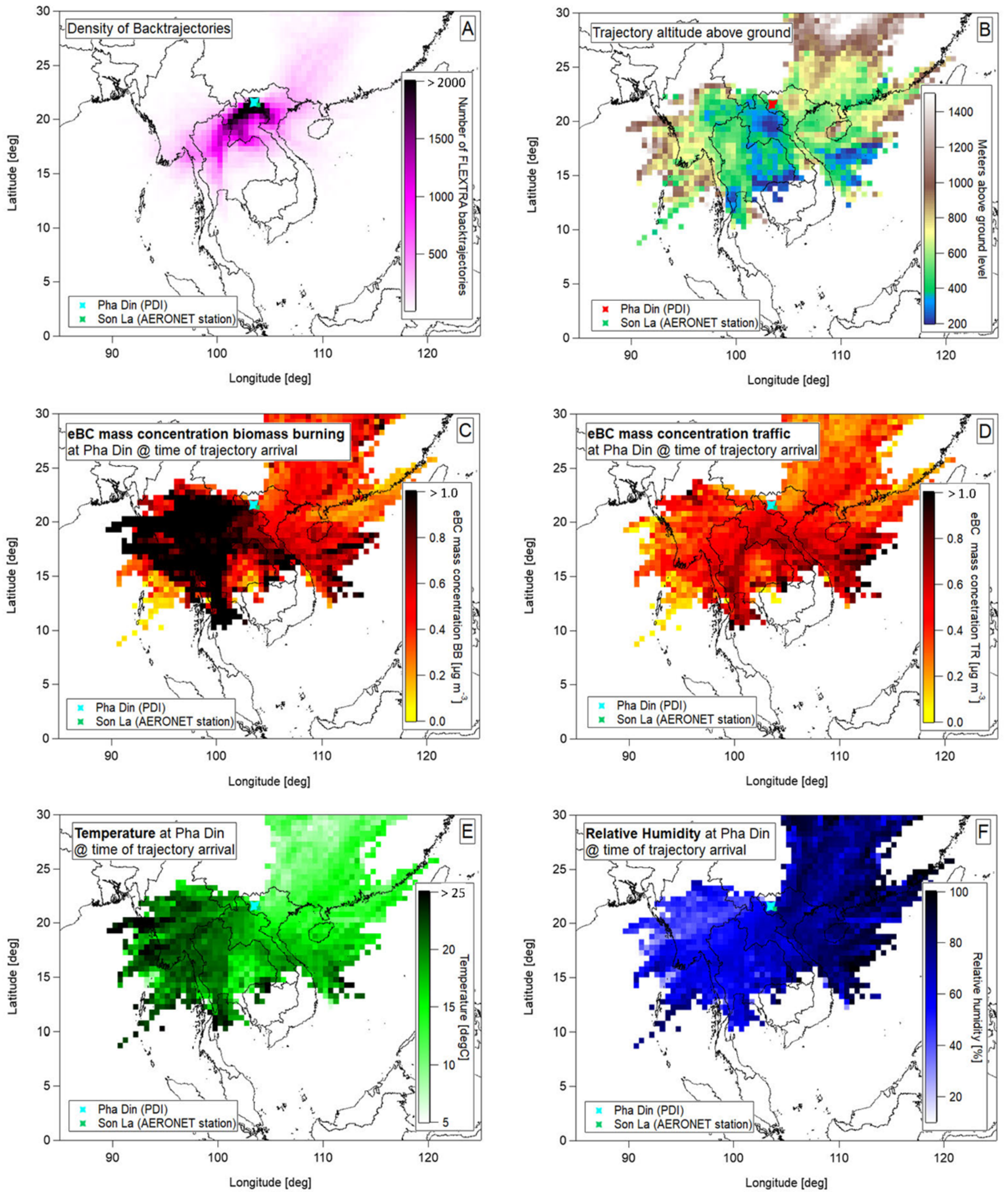

Fig. 5. Source regions for $B B$ and traffic eBC mass concentrations during the winter tropical SE Asian high pressure system, derived from 3-day FLEXTRA back-trajectories. The 3-day FLEXTRA back-trajectories were mapped into a grid with a horizontal resolution of $0.5^{\circ} \times 0.5^{\circ}$ (trajectory density shown in panel A). For each trajectory in an individual grid cell the aerosol/meteorological parameters measured at Pha Din at the time of the trajectory arrival is assigned to the cell, and the average of all values assigned to a grid cell is formed. 

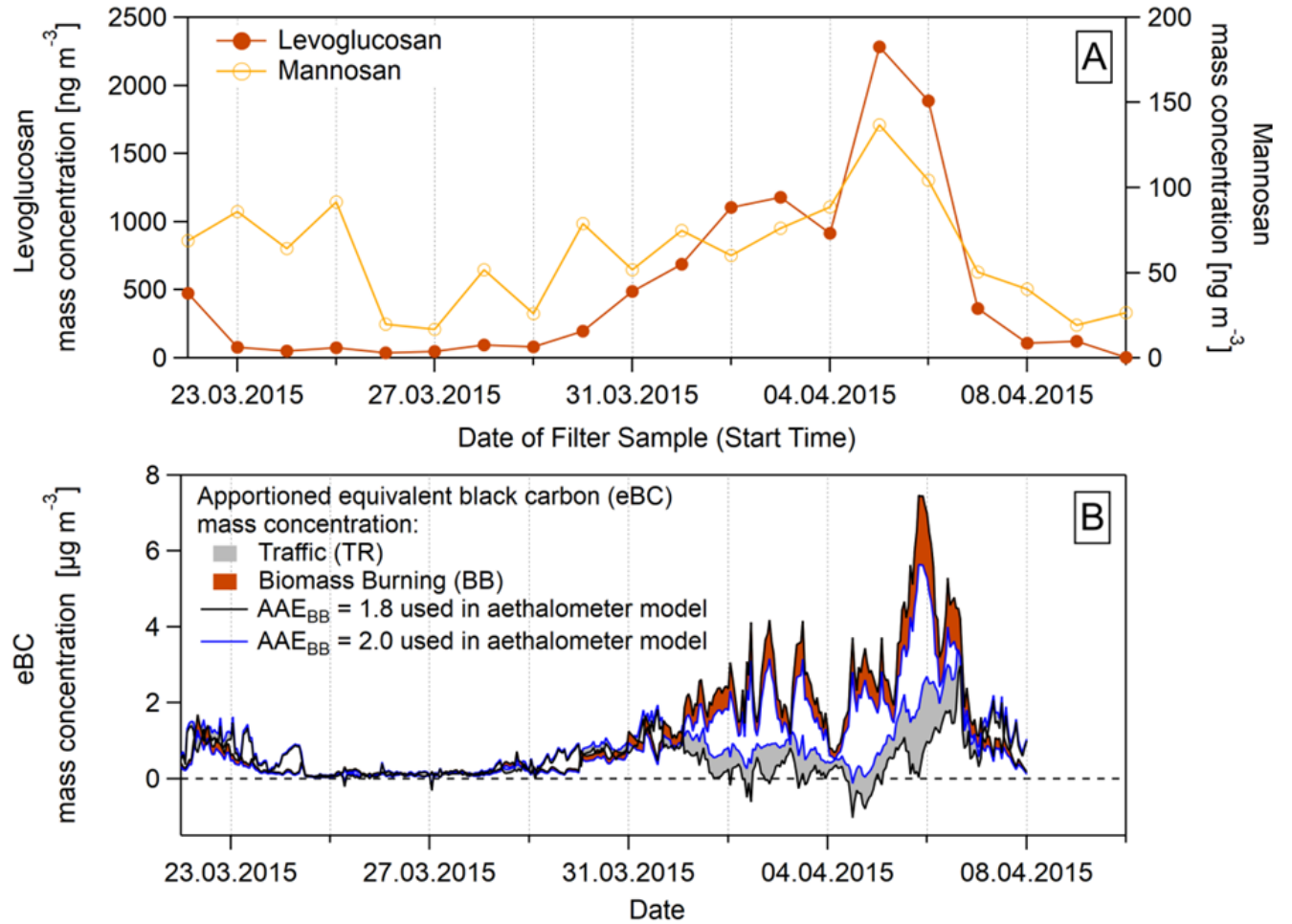

Fig. 6. (A) Timeline of biomass burning marker mass concentrations (levoglucosan and mannosan) during an intensive measurement campaign at Pha Din during spring, 2015. Daily values are shown (markers represent start time) and (B) BB and traffic eBC mass concentrations, apportioned by the aethalometer model.

Despite the difference in location and methodology (ground-based in situ measurements vs. column-integrated measurements), the EAE values (top panel) do not significantly differ, and the time series follow the same general pattern. In contrast, the AAE comparison shows lower values for the AERONET measurements at Son La. To assess this difference in a more quantitative way, all available data between 2014 and 2017 were taken into account (see Fig. S10(a)-10(b)) in the Supplementary Information). On average, the Son La AERONET AAE ambient values are $20 \%$ lower compared to the Pha Din in-situ values and show a large lower interquartile range caused by occasionally very low AERONET AAE $\mathrm{Ambient}_{\text {values. Besides }}$ the general methodological differences in the sampled volume (in-situ vs. column), it is also likely that the lower $\mathrm{AAE}_{\text {ambient }}$ values at Son $\mathrm{La}$ are caused by a stronger influence from traffic sources within the PBL above the Son La site (i.e., a lower ratio of brown carbon to EC in the traffic emissions compared to BB emissions). Fig. 7(B) compares the SSA retrieved by the two methods, again for the same period in 2015. Since the ambient relative humidity was low during the peak of the BB event $(40 \%$ at Pha Din and $50 \%$ in Son La), the in-situ values compare well with the AERONET SSA values. Before and after this event, the ambient RH is considerably higher, and the AERONET SSA is correspondingly higher as a result of the scattering enhancement by water uptake (see Eq. (7)).

Scattering enhancement by water uptake, commonly described by a wavelength dependent scattering enhancement factor, $f(\mathrm{RH})$ (Zieger et al., 2015), plays an important role when retrieving scattering coefficients, extinction coefficients and SSA values for the Pha Din in-situ measurements, which are measured under dry conditions according to the GAW recommendations (see "Methods"). Fig. 8 shows the correlation between the in-situ and AERONET SSA for all available data between 2014 and 2017 for two wavelengths, additionally color coded by the ambient relative humidity. The plot first of all shows that with the consistently dry conditions during the BB events (low SSA values), the SSA values are closer to the 1:1 line compared to the other time periods with higher SSA and higher ambient RH. The agreement is slightly better for the red wavelength, while the offset seems higher for the blue wavelength.

The good agreement between in-situ and remote sensing measurements during the dry conditions supports the general comparability and good quality of these data. It can therefore be assumed that discrepancies during higher $\mathrm{RH}$ are truly caused by light scattering enhancement effects. To obtain an idea of the quantitative range of the expected scattering enhancement for the aerosol at Pha Din, "climatology-based $f(\mathrm{RH}, \lambda)_{\text {clim }}$ " values for SSA were determined according to Eq. (7) by selecting an $f(\mathrm{RH}, \lambda)$ so that the in-situ SSA matches the AERONET SSA. This approach is based on the assumption that the aerosol absorption coefficient is only weakly dependent on RH (Nessler et al., 2005). Fig. 9 shows the determined $f(\mathrm{RH}, \lambda)_{\text {clim }}$ plotted against RH. The upper panels of Fig. 9 are color coded with $b_{\text {abs }}$ and the lower panels, with $b_{\text {scat }}$. The color coding shows, - in accordance with the trajectory plots in Figs. 5(C) and 5(F) - , that the aerosol concentration and 


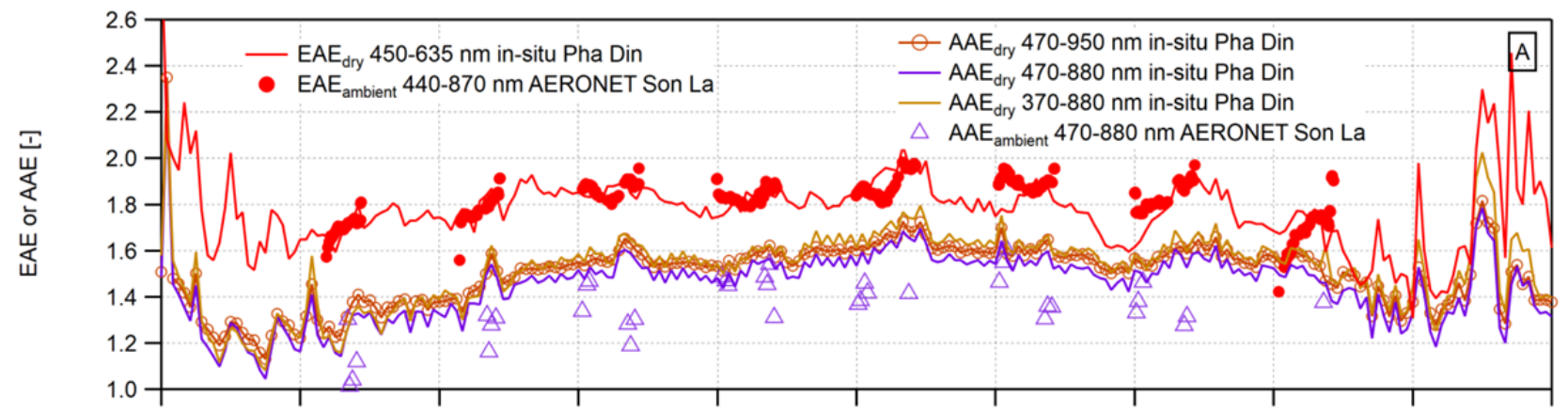

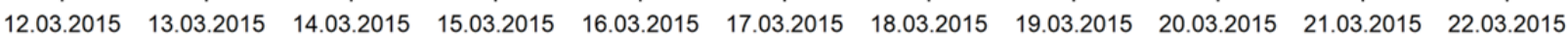
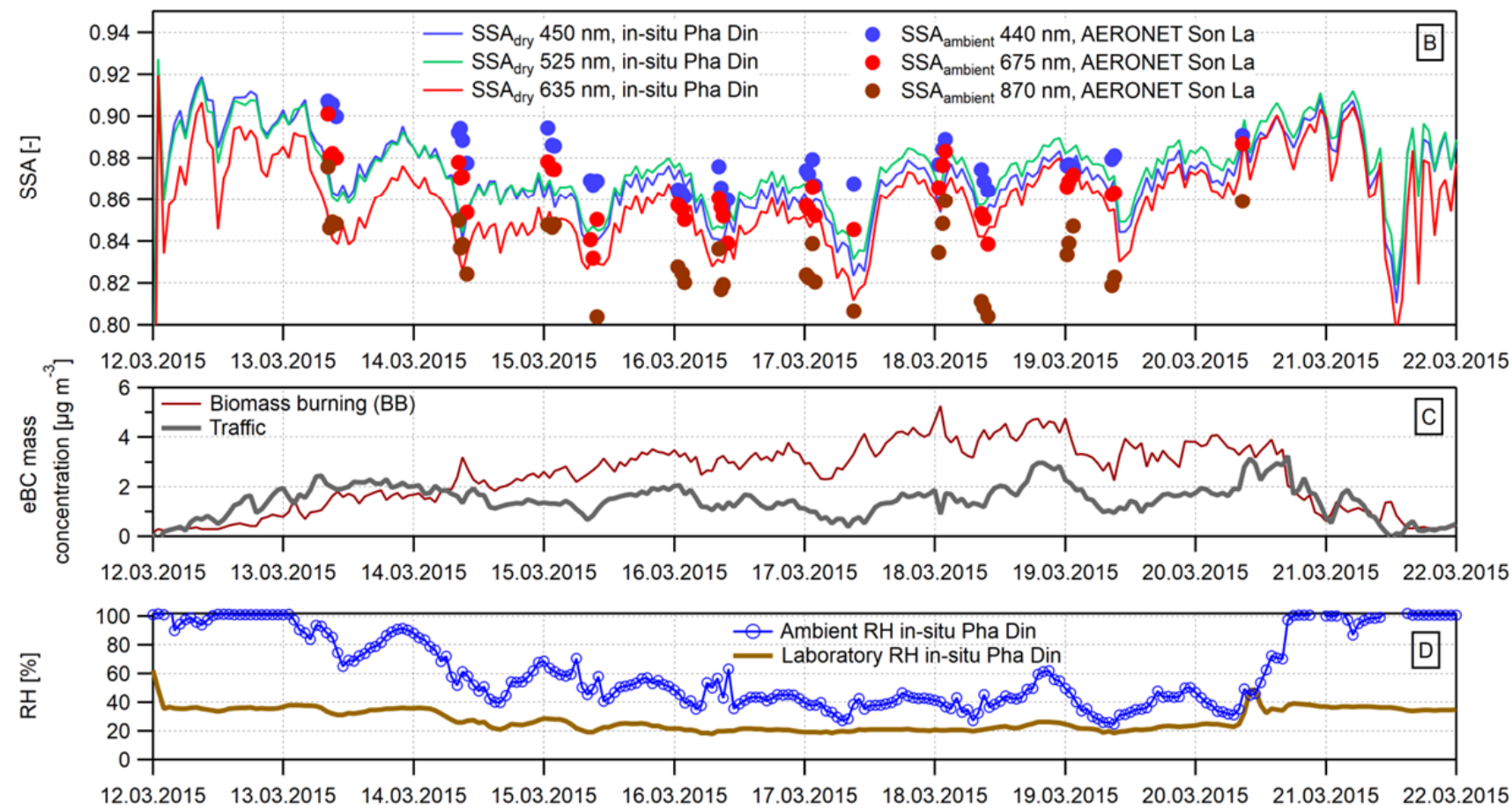

Fig. 7. (A) Extinction Angstrom exponent (EAE) and absorption Angstrom exponent (AAE) from ground based in-situ measurements at Pha Din and column-based measurements in Son La (48 km distance from Pha Din) during a high biomass burning episode in March 2015, (B) Single scattering albedo (SSA), calculated for the three nephelometer wavelengths by interpolation of the 7-wavelength aethalometer data, $(\mathrm{C})$ eBC mass concentration, apportioned into $\mathrm{BB}$ and traffic contributions by the aethalometer model (using $\mathrm{AAE}_{\mathrm{BB}}=1.8$ in the model) and (D) ambient and laboratory relative humidity.

RH exhibit substantial co-variance at Pha Din: there is a general trend of increasing median $b_{\mathrm{abs}}$ and $b_{\text {scat }}$ with decreasing $\mathrm{RH}$. Whereas during high $b_{\mathrm{abs}}$ events with low relative humidity, $f(\mathrm{RH}, \lambda)_{\text {clim }}$ is close to unity, $f(\mathrm{RH}, \lambda)_{\text {clim }}$ increases to $\sim 1.5$ (interquartile range: 1.2-2) during the other time periods with high ambient $\mathrm{RH}$ and low ambient concentrations of $b_{\mathrm{abs}}$ (i.e., the wet season from June to September). Thus, the dry in-situ measured $b_{\text {scat }}$ or SSA values are lower than the corresponding values under ambient conditions. The climatology-based $f(\mathrm{RH}, \lambda)_{\text {clim }}$ values for Pha Din compare well with the few values available in the literature for this region, e.g., an $f(\mathrm{RH}, \lambda)$ value of 1.2 at a $450 \mathrm{~nm}$ wavelength for $85 \% \mathrm{RH}$ for near-source BB aerosol in northern Thailand using wet nephelometry (Pantina et al., 2016). Finally, the climatology-based $f(\mathrm{RH}, \lambda)_{\text {clim }}$ values in Fig. 9 also allow for a simple estimate of the effect of
$\mathrm{RH}$ on SAE. Based on the $f(\mathrm{RH}, \lambda)_{\text {clim }}$ values at $450 \mathrm{~nm}$ (median values of 1.2 and 1.4 for $30 \%$ and $70 \% \mathrm{RH}$, respectively) and at $675 \mathrm{~nm}$ (median values of 1.1 and 1.6 for $30 \%$ and $70 \% \mathrm{RH}$, respectively), SAE decreases by approx. $20 \%$ at $70 \%$ RH compared to the dry value.

\section{CONCLUSIONS}

This study presents for the first time results from multiannual continuous ground-based in-situ aerosol monitoring at a remote site in northern SE Asia. A clear correlation between the time series of the absorption coefficient values and satellite detected land fire hotspots exists, with decreasing peak intensities in the last five years. Also, the ground-based in-situ aerosol data measured at Pha Din agree well with the semi-continuous AERONET data from 

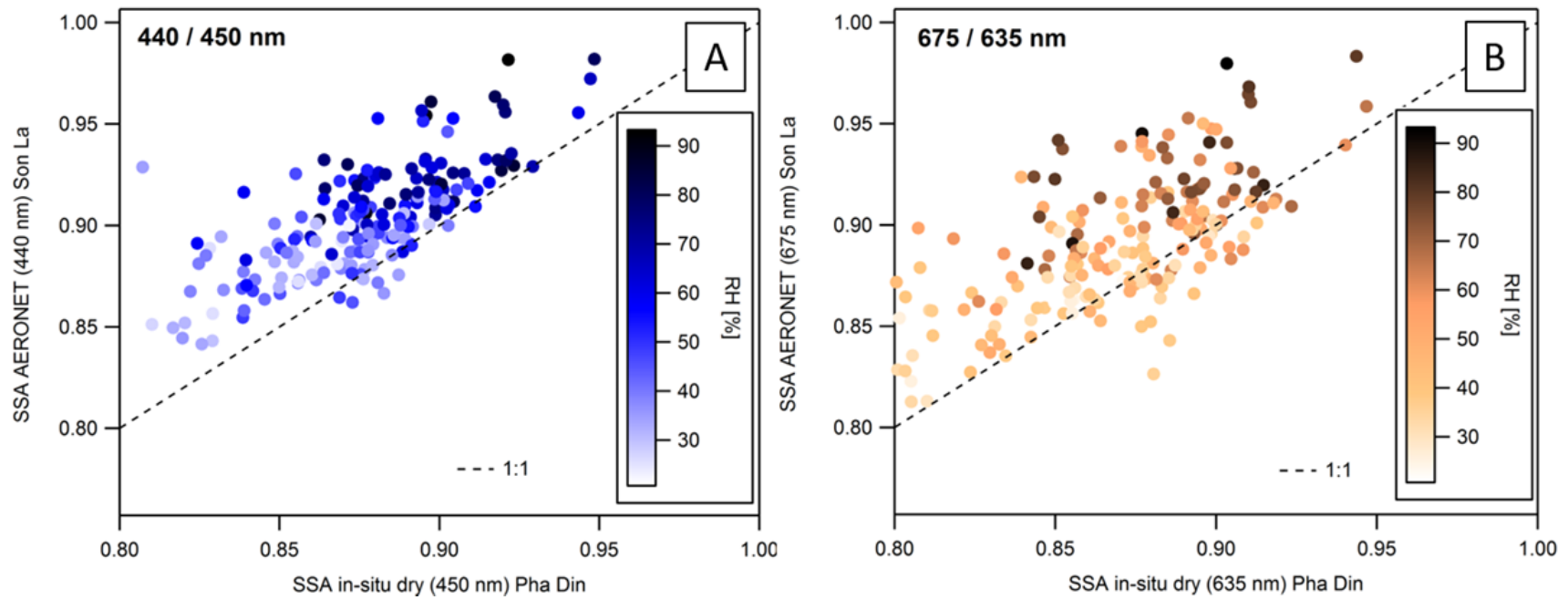

Fig. 8. Comparison between the single scattering albedo (SSA) retrieved from AERONET measurements at Son La (48 km distance from Pha Din) and the SSA (dry sampling conditions, see WMO/GAW, 2017) retrieved from the groundbased in-situ measurements at Pha Din. Data points represent all hourly values from 2014-2017 with existing simultaneous in-situ and AERONET data. The comparison was made for two wavelengths (panel A: blue, 440/450 nm, panel B: red, 675/635 $\mathrm{nm}$ ). Data points are color coded with the ambient relative humidity.
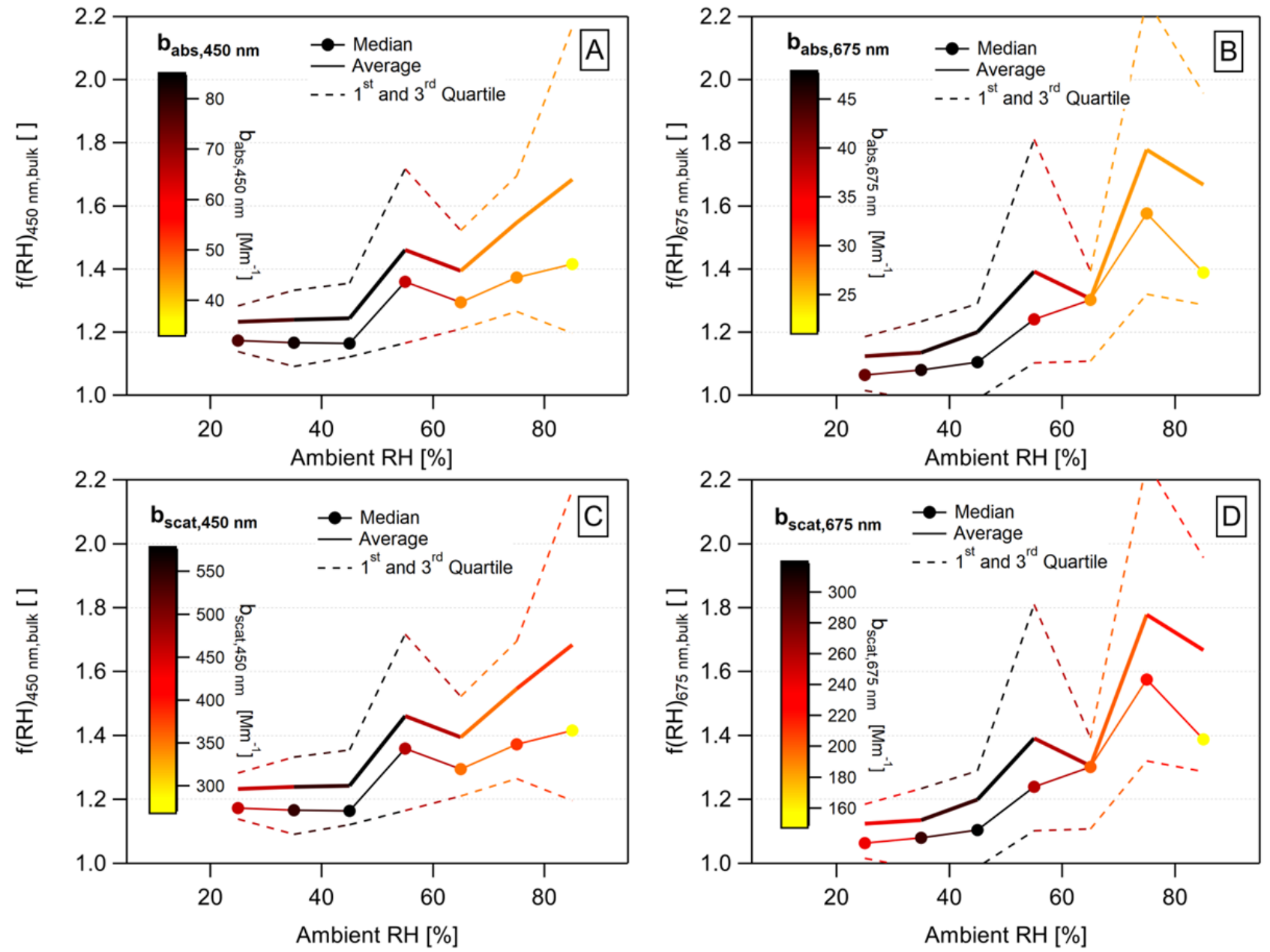

Fig. 9. Climatology-based scattering enhancement factor $\mathrm{f}(\mathrm{RH})$ plotted against relative humidity. The comparison was made for two wavelengths (left panel: $450 \mathrm{~nm}$, right panel: $675 \mathrm{~nm}$ ). Data points are color coded with the absorption coefficient (panels A and B) and the scattering coefficient (panels $C$ and D). The plots are retrieved from all hourly values during 2014-2017 with existing simultaneous in-situ data (Pha Din) and AERONET data (Son La). 
the Son La site, which is $50 \mathrm{~km}$ from Pha Din. Due to the consistently low ambient relative humidity during the peak BB periods $(<50 \% \mathrm{RH}), \mathrm{RH}$ dependent parameters, such as $b_{\text {scat }}$ or SSA, retrieved from dry ground-based in situ measurements at Pha Din can also be considered to be reasonably representative for ambient conditions during the dry season. Finally, the findings based on the continuous monitoring help to tie together past data obtained during temporally restricted aerosol measurements in the region. Thus, the aerosol monitoring at Pha Din offers an important contribution to a quantitative assessment of the biomass burning impact on regional air quality in northern SE Asia.

\section{ACKNOWLEDGMENTS}

We acknowledge the support of the Federal Office of Meteorology and Climatology MeteoSwiss through the project Capacity Building and Twinning for Climate Observing Systems (CATCOS) Phase 1 and Phase 2, Contract No. 81025332 between the Swiss Agency for Development and Cooperation (SDC) and MeteoSwiss. We also acknowledge the use of imagery from the NASA Worldview application (https://worldview.earthdata.nasa.gov/) operated by the NASA/Goddard Space Flight Center Earth Science Data and Information System (ESDIS) project. MG received financial support from the ERC under grant no. ERC-CoG-615922-BLACARAT. The AERONET measurements at Son La are supported by the Vietnam Academy of Science and Technology (project code QTRU05.01/18-20).

\section{SUPPLEMENTARY MATERIAL}

Supplementary data associated with this article can be found in the online version at http://www.aaqr.org.

\section{REFERENCES}

AERONET (2018). https://aeronet.gsfc.nasa.gov/, Last Access: 13 February 2018.

Andrews, E., Ogren, J.A., Bonasoni, P., Marinoni, A., Cuevas, E., Rodríguez, S., Sun, J.Y., Jaffe, D.A., Fischer, E.V., Baltensperger, U., Weingartner, E., Coen, M.C., Sharma, S., Macdonald, A.M., Leaitch, W.R., Lin, N.H., Laj, P., Arsov, T., Kalapov, I., Jefferson, A. and Sheridan, P. (2011). Climatology of aerosol radiative properties in the free troposphere. Atmos. Res. 102: 365-393.

Arellano, A.F., Kasibhatla, P.S., Giglio, L., van der Werf, G.R., Randerson, J.T. and Collatz, G.J. (2006). Timedependent inversion estimates of global biomass-burning $\mathrm{CO}$ emissions using Measurement of Pollution in the Troposphere (MOPITT) measurements. J. Geophys. Res. 111: D09303.

ASMC (2018). http://asmc.asean.org/asmc-haze-hotspotmonthly\#Hotspot, Last Access: 23 August 2018.

Bond, T.C., Doherty, S.J., Fahey, D.W., Forster, P.M., Berntsen, T., DeAngelo, B.J., Flanner, M.G., Ghan, S., Kärcher, B., Koch, D., Kinne, S., Kondo, Y., Quinn,
P.K., Sarofim, M.C., Schultz, M.G., Schulz, M., Venkataraman, C., Zhang, H., Zhang, S., Bellouin, N., Guttikunda, S.K., Hopke, P.K., Jacobson, M.Z., Kaiser, J.W., Klimont, Z., Lohmann, U., Schwarz, J.P., Shindell, D., Storelvmo, T., Warren, S.G. and Zender, C.S. (2013). Bounding the role of black carbon in the climate system: A scientific assessment. J. Geophys. Res. 118: 5380-5552.

Bösendorfer, J., Ansmann, A., Baldasano, J. M., Balis, D., Bockmann, C., Calpini, B., Chaikovsky, A., Flamant, P., Hagard, A., Mitev, V., Papayannis, A., Pelon, J., Resendes, D., Schneider, J., Spinelli, N., Trickl, T., Vaughan, G., Visconti, G. and Wiegner, M. (2001). EARLINET: A European aerosol research lidar network. In Advances in laser remote sensing, Dabas, A., Loth, C. and Pelon, J. (Eds.), ISBN 2-7302-0798-8.

Boucher, O., Randall, D., Artaxo, P., Bretherton, C., Feingold, G., Forster, P., Kerminen, V.M., Kondo, Y., Liao, H., Lohmann, U., Rasch, P., Satheesh, S.K., Sherwood, S., Stevens, B. and Zhang, X.Y. (2013). Clouds and aerosols. In Climate Change 2013: The physical science basis. Contribution of working Group I to the Fifth assessment report of the intergovernmental panel on climate change, Stocker, T.F., Qin, D., Plattner, G.K., Tignor, M., Allen, S.K., Boschung, J., Nauels, A., Xia, Y., Bex, V. and Midgley, P.M. (Eds.), Cambridge University Press, Cambridge, United Kingdom and New York, NY, USA, pp. 571-658.

Carmichael, G.R., Tang, Y., Kurata, G., Uno, I., Streets, D., Woo, J.H., Huang, H., Yienger, J., Lefer, B., Shetter, R., Blake, D., Atlas, E., Fried, A., Apel, E., Eisele, F., Cantrell, C., Avery, M., Barrick, J., Sachse, G., Brune, W., Sandholm, S., Kondo, Y., Singh, H., Talbot, R., Bandy, A., Thorton, D., Clarke, A. and Heikes, B. (2003). Regional-scale chemical transport modeling in support of the analysis of observations obtained during the TRACE-P experiment. J. Geophys. Res. 108: 8823.

Cazorla, A., Bahadur, R., Suski, K.J., Cahill, J.F., Chand, D., Schmid, B., Ramanathan, V. and Prather, K.A. (2013). Relating aerosol absorption due to soot, organic carbon, and dust to emission sources determined from in-situ chemical measurements. Atmos. Chem. Phys. 13: 9337-9350.

Chen, T.C., Yen, M.C., Huang, W.R. and Gallus, W.A. (2002). An East Asian cold surge: Case study. Mon. Weather Rev. 130: 2271-2290.

Co, H.X., Dung, N.T., Oanh, N.T.K., Hang, N.T., Phuc, N.H. and Le, H.A. (2014). Levels and composition of ambient particulate matter at a mountainous rural site in northern Vietnam. Aerosol Air Qual. Res. 14: 19171928.

Collaud Coen, M., Weingartner, E., Apituley, A., Ceburnis, D., Fierz-Schmidhauser, R., Flentje, H., Henzing, J.S., Jennings, S.G., Moerman, M., Petzold, A., Schmid, O. and Baltensperger, U. (2010). Minimizing light absorption measurement artifacts of the Aethalometer: Evaluation of five correction algorithms. Atmos. Meas. Tech. 3: 457-474.

Collaud Coen, M., Andrews, E., Asmi, A., Baltensperger, 
U., Bukowiecki, N., Day, D., Fiebig, M., Fjaeraa, A.M., Flentje, H., Hyvärinen, A., Jefferson, A., Jennings, S.G., Kouvarakis, G., Lihavainen, H., Lund Myhre, C., Malm, W.C., Mihapopoulos, N., Molenar, J.V., O'Dowd, C., Ogren, J.A., Schichtel, B.A., Sheridan, P., Virkkula, A., Weingartner, E., Weller, R. and Laj, P. (2013). Aerosol decadal trends - Part 1: In-situ optical measurements at GAW and IMPROVE stations. Atmos. Chem. Phys. 13: 869-894.

Drinovec, L., Močnik, G., Zotter, P., Prévôt, A.S.H., Ruckstuhl, C., Coz, E., Rupakheti, M., Sciare, J., Müller, T., Wiedensohler, A. and Hansen, A.D.A. (2015). The "dual-spot" Aethalometer: An improved measurement of aerosol black carbon with real-time loading compensation. Atmos. Meas. Tech. 8: 1965-1979.

Dubovik, O. and King, M.D. (2000). A flexible inversion algorithm for retrieval of aerosol optical properties from Sun and sky radiance measurements. J. Geophys. Res. 105: 20673-20696.

Dubovik, O., Smirnov, A., Holben, B.N., King, M.D., Kaufman, Y.J., Eck, T.F. and Slutsker, I. (2000). Accuracy assessments of aerosol optical properties retrieved from Aerosol Robotic Network (AERONET) Sun and sky radiance measurements. J. Geophys. Res. 105: 9791-9806.

Dubovik, O., Sinyuk, A., Lapyonok, T., Holben, B.N., Mishchenko, M., Yang, P., Eck, T.F., Volten, H., Muñoz, O., Veihelmann, B., van der Zande, W.J., Leon, J.F., Sorokin, M. and Slutsker, I. (2006). Application of spheroid models to account for aerosol particle nonsphericity in remote sensing of desert dust. $J$. Geophys. Res. 111: D11208.

Duc, H.N., Bang, H.Q. and Quang, N.X. (2016). Modelling and prediction of air pollutant transport during the 2014 biomass burning and forest fires in peninsular Southeast Asia. Environ. Monit. Assess. 188: 106.

Duncan, B.N., Logan, J.A., Bey, I., Megretskaia, I.A., Yantosca, R.M., Novelli, P.C., Jones, N.B. and Rinsland, C.P. (2007). Global budget of CO, 1988-1997: Source estimates and validation with a global model. J. Geophys. Res. 112: D22301.

Engling, G., Carrico, C.M., Kreidenweis, S.M., Collett, J.L., Day, D.E., Malm, W.C., Lincoln, E., Min Hao, W., Iinuma, Y. and Herrmann, H. (2006). Determination of levoglucosan in biomass combustion aerosol by highperformance anion-exchange chromatography with pulsed amperometric detection. Atmos. Environ. 40: 299-311.

Fang, S., Tans, P.P., Steinbacher, M., Zhou, L., Luan, T. and Li, Z. (2016). Observation of atmospheric $\mathrm{CO}_{2}$ and $\mathrm{CO}$ at Shangri-La station: Results from the only regional station located at southwestern China. Tellus $B$ 68: 28506.

Forster, P., Ramaswamy, V., Artaxo, P., Berntsen, T., Betts, R., Fahey, D.W., Haywood, J., Lean, J., Lowe, D.C., Myhre, G., Nganga, J., Prinn, R., Raga, G., Schultz, M. and Van Dorland, R. (2007). Changes in atmospheric constituents and in radiative forcing.
Solomon, S., Qin, D., Manning, M., Chen, Z., Marquis, M., Averyt, K.B., Tignor, M. and Miller, H.L. (Eds.), Cambridge University Press, Cambridge, United Kingdom, pp. 129-234.

Franke, V., Zieger, P., Wideqvist, U., Acosta Navarro, J.C., Leck, C., Tunved, P., Rosati, B., Gysel, M., Salter, M.E. and Ström, J. (2017). Chemical composition and source analysis of carbonaceous aerosol particles at a mountaintop site in central Sweden. Tellus $B$ 69: 1353387.

Gautam, R., Hsu, N.C., Eck, T.F., Holben, B.N., Janjai, S., Jantarach, T., Tsay, S.C. and Lau, W.K. (2013). Characterization of aerosols over the Indochina peninsula from satellite-surface observations during biomass burning pre-monsoon season. Atmos. Environ. 78: 51-59.

Holben, B.N., Eck, T.F., Slutsker, I., Tanré, D., Buis, J.P., Setzer, A., Vermote, E., Reagan, J.A., Kaufman, Y.J., Nakajima, T., Lavenu, F., Jankowiak, I. and Smirnov, A. (1998). AERONET - A federated instrument network and data archive for aerosol characterization. Remote Sens. Environ. 66: 1-16.

Holben, B.N., Eck, T.F., Slutsker, I., Smirnov, A., Sinyuk, A., Schafer, J., Giles, D. and Dubovik, O. (2006). SPIE Asia-Pacific remote sensing, 2006, SPIE, p. 14.

Holloway, T., Levy, H. and Kasibhatla, P. (2000). Global distribution of carbon monoxide. J. Geophys. Res. 105: 12123-12147.

Jaeglé, L., Quinn, P.K., Bates, T.S., Alexander, B. and Lin, J.T. (2011). Global distribution of sea salt aerosols: New constraints from in situ and remote sensing observations. Atmos. Chem. Phys. 11: 3137-3157.

Kaskaoutis, D.G., Kumar, S., Sharma, D., Singh, R.P., Kharol, S.K., Sharma, M., Singh, A.K., Singh, S., Singh, A. and Singh, D. (2014). Effects of CRB on aerosol properties, plume characteristics, and long-range transport over northern India. J. Geophys. Res. 119: 5424-5444.

Kirchstetter, T.W., Novakov, T. and Hobbs, P.V. (2004). Evidence that the spectral dependence of light absorption by aerosols is affected by organic carbon. $J$. Geophys. Res. 109: D21208.

Krishna Prasad, V., Kristofer, L., Louis, G. and Chris, J. (2015). Vegetation fires, absorbing aerosols and smoke plume characteristics in diverse biomass burning regions of Asia. Environ. Res. Lett. 10: 105003.

Li, J., Zhang, Y., Wang, Z., Sun, Y., Fu, P., Yang, Y., Huang, H., Li, J., Zhang, Q., Lin, C. and Lin, N.H. (2017). Regional impact of biomass burning in southeast Asia on atmospheric aerosols during the 2013 Seven South-East Asian Studies project. Aerosol Air Qual. Res. 17: 2924-2941.

Lin, C.C., Chen, W.N., Loftus, A.M., Lin, C.Y., Fu, Y.T., Peng, C.M. and Yen, M.C. (2017). Influences of the long-range transport of biomass-burning pollutants on surface air quality during 7-SEAS field campaigns. Aerosol Air Qual. Res. 17: 2595-2607.

Lin, N.H., Tsay, S.C., Maring, H.B., Yen, M.C., Sheu, G.R., Wang, S.H., Chi, K.H., Chuang, M.T., Ou-Yang, C.F., Fu, J.S., Reid, J.S., Lee, C.T., Wang, L.C., Wang, J.L., Hsu, C.N., Sayer, A.M., Holben, B.N., Chu, Y.C., 
Nguyen, X.A., Sopajaree, K., Chen, S.J., Cheng, M.T., Tsuang, B.J., Tsai, C.J., Peng, C.M., Schnell, R.C., Conway, T., Chang, C.T., Lin, K.S., Tsai, Y.I., Lee, W.J., Chang, S.C., Liu, J.J., Chiang, W.L., Huang, S.J., Lin, T.H. and Liu, G.R. (2013). An overview of regional experiments on biomass burning aerosols and related pollutants in Southeast Asia: From BASE-ASIA and the Dongsha Experiment to 7-SEAS. Atmos. Environ. 78: $1-19$.

Liousse, C., Cachier, H. and Jennings, S.G. (1993). Optical and thermal measurements of black carbon aerosol content in different environments: Variation of the specific attenuation cross-section, sigma $(\sigma)$. Atmos. Environ. 27: 1203-1211.

Loftus, A.M., Tsay, S.C., Pantina, P., Nguyen, C., Gabriel, P.M., Nguyen, X.A., Sayer, A.M., Tao, W.K. and Matsui, T. (2016). Coupled aerosol-cloud systems over northern Vietnam during 7-SEAS/BASELInE: A radar and modeling perspective. Aerosol Air Qual. Res. 16: 2768-2785.

Lopatin, A., Dubovik, O., Chaikovsky, A., Goloub, P., Lapyonok, T., Tanré, D. and Litvinov, P. (2013). Enhancement of aerosol characterization using synergy of lidar and sun-photometer coincident observations: The GARRLiC algorithm. Atmos. Meas. Tech. 6: 20652088.

Mann, G.W., Carslaw, K.S., Reddington, C.L., Pringle, K.J., Schulz, M., Asmi, A., Spracklen, D.V., Ridley, D.A., Woodhouse, M.T., Lee, L.A., Zhang, K., Ghan, S.J., Easter, R.C., Liu, X., Stier, P., Lee, Y.H., Adams, P.J., Tost, H., Lelieveld, J., Bauer, S.E., Tsigaridis, K., van Noije, T.P.C., Strunk, A., Vignati, E., Bellouin, N., Dalvi, M., Johnson, C.E., Bergman, T., Kokkola, H., von Salzen, K., Yu, F., Luo, G., Petzold, A., Heintzenberg, J., Clarke, A., Ogren, J.A., Gras, J., Baltensperger, U., Kaminski, U., Jennings, S.G., O'Dowd, C.D., Harrison, R.M., Beddows, D.C.S., Kulmala, M., Viisanen, Y., Ulevicius, V., Mihalopoulos, N., Zdimal, V., Fiebig, M., Hansson, H.C., Swietlicki, E. and Henzing, J.S. (2014). Intercomparison and evaluation of global aerosol microphysical properties among AeroCom models of a range of complexity. Atmos. Chem. Phys. 14: 46794713.

MONRE (2012). National technical regulation on meteorological observations. Report Number QCVN 46: 2012/BTNMT.

Müller, T., Laborde, M., Kassell, G. and Wiedensohler, A. (2011). Design and performance of a three-wavelength LED-based total scatter and backscatter integrating nephelometer. Atmos. Meas. Tech. 4: 1291-1303.

Nessler, R., Weingartner, E. and Baltensperger, U. (2005). Effect of humidity on aerosol light absorption and its implications for extinction and the single scattering albedo illustrated for a site in the lower free troposphere. J. Aerosol Sci. 36: 958-972.

Nguyen, D.L., Kawamura, K., Ono, K., Ram, S.S., Engling, G., Lee, C.T., Lin, N.H., Chang, S.C., Chuang, M.T., Hsiao, T.C., Sheu, G.R., Ou Yang, C.F., Chi, K.H. and Sun, S.A. (2016). Comprehensive $\mathrm{PM}_{2.5}$ Organic molecular composition and stable carbon isotope ratios at Sonla, Vietnam: Fingerprint of biomass burning components. Aerosol Air Qual. Res. 16: 2618-2634.

Pantina, P., Tsay, S.C., Hsiao, T.C., Loftus, A.M., Kuo, F., Ou-Yang, C.F., Sayer, A.M., Wang, S.H., Lin, N.H., Hsu, N.C., Janjai, S., Chantara, S. and Nguyen, A.X. (2016). COMMIT in 7-SEAS/BASELInE: Operation of and observations from a novel, mobile laboratory for measuring in-situ properties of aerosols and gases. Aerosol Air Qual. Res. 16: 2728-2741.

Park, S.S., Hansen, A.D.A. and Cho, S.Y. (2010). Measurement of real time black carbon for investigating spot loading effects of Aethalometer data. Atmos. Environ. 44: 1449-1455.

Petzold, A., Kopp, C. and Niessner, R. (1997). The dependence of the specific attenuation cross-section on black carbon mass fraction and particle size. Atmos. Environ. 31: 661-672.

Popovicheva, O.B., Engling, G., Diapouli, E., Saraga, D., Persiantseva, N.M., Timofeev, M.A., Kireeva, E.D., Shonija, N.K., Chen, S.H., Nguyen, D.L., Eleftheriadis, K. and Lee, C.T. (2016). Impact of smoke intensity on size-resolved aerosol composition and microstructure during the biomass burning season in Northwest Vietnam. Aerosol Air Qual. Res. 16: 2635-2654.

Samset, B.H., Myhre, G., Herber, A., Kondo, Y., Li, S.M., Moteki, N., Koike, M., Oshima, N., Schwarz, J.P., Balkanski, Y., Bauer, S.E., Bellouin, N., Berntsen, T.K., Bian, H., Chin, M., Diehl, T., Easter, R.C., Ghan, S.J., Iversen, T., Kirkevåg, A., Lamarque, J.F., Lin, G., Liu, X., Penner, J.E., Schulz, M., Seland, Ø., Skeie, R.B., Stier, P., Takemura, T., Tsigaridis, K. and Zhang, K. (2014). Modelled black carbon radiative forcing and atmospheric lifetime in AeroCom Phase II constrained by aircraft observations. Atmos. Chem. Phys. 14: 1246512477.

Sandradewi, J., Prévôt, A.S.H., Szidat, S., Perron, N., Alfarra, M.R., Lanz, V.A., Weingartner, E. and Baltensperger, U. (2008). Using aerosol light absorption measurements for the quantitative determination of wood burning and traffic emission contributions to particulate matter. Environ. Sci. Technol. 42: 33163323.

Sarkar, S., Singh, R.P. and Chauhan, A. (2018). Crop residue burning innorthern India: Increasing threat to greater India. J. Geophys. Res. 123: D028428

Schultz, M.G., Heil, A., Hoelzemann, J.J., Spessa, A., Thonicke, K., Goldammer, J.G., Held, A.C., Pereira, J.M.C. and van het Bolscher, M. (2008). Global wildland fire emissions from 1960 to 2000. Global Biogeochem. Cycles 22: GB2002.

SDC (2018). https://www.eda.admin.ch/deza/en/home/act ivities-projects/projekte-fokus/Project-database.filterRes ults.html/dezaprojects/SDC/en/2011/7F08114/phase2, Last Access: 11 October 2018.

Simoneit, B.R.T., Schauer, J.J., Nolte, C.G., Oros, D.R., Elias, V.O., Fraser, M.P., Rogge, W.F. and Cass, G.R. (1999). Levoglucosan, a tracer for cellulose in biomass burning and atmospheric particles. Atmos. Environ. 33: 
$173-182$

Simoneit, B.R.T. and Elias, V.O. (2001). Detecting organic tracers from biomass burning in the atmosphere. Mar. Pollut. Bull. 42: 805-810.

Simoneit, B.R.T (2002). Biomass burning-A review of organic tracers for smoke from incomplete combustion. Appl. Geochem. 17: 129-162.

Skupin, A., Ansmann, A., Engelmann, R., Seifert, P. and Müller, T. (2016). Four-year long-path monitoring of ambient aerosol extinction at a central European urban site: dependence on relative humidity. Atmos. Chem. Phys. 16: 1863-1876.

Stohl, A., Wotawa, G., Seibert, P. and Krompkolb, H. (1995). Interpolation errors in wind fields as a function of spatial and temporal resolution and their impact on different types of kinematic trajectories. J. Appl. Meteorol. 34: 2149-2165.

Stohl, A. and Seibert, P. (1998). Accuracy of trajectories as determined from the conservation of meteorological tracers. Q. J. R. Meteorolog. Soc. 124: 1465-1484.

Streets, D.G., Yarber, K.F., Woo, J.H. and Carmichael, G.R. (2003). Biomass burning in Asia: Annual and seasonal estimates and atmospheric emissions. Global Biogeochem. Cycles 17: 1099.

Streets, D.G., Yan, F., Chin, M., Diehl, T., Mahowald, N., Schultz, M., Wild, M., Wu, Y. and Yu, C. (2009). Anthropogenic and natural contributions to regional trends in aerosol optical depth, 1980-2006. J. Geophys. Res. 114: D00D18.

van der Werf, G.R., Randerson, J.T., Giglio, L., Collatz, G.J., Kasibhatla, P.S. and Arellano Jr, A.F. (2006). Interannual variability in global biomass burning emissions from 1997 to 2004. Atmos. Chem. Phys. 6: 3423-3441.

Wang, S.H., Welton, E.J., Holben, B.N., Tsay, S.C., Lin, N.H., Giles, D., Stewart, S.A., Janjai, S., Nguyen, X.A., Hsiao, T.C., Chen, W.N., Lin, T.H., Buntoung, S., Chantara, S. and Wiriya, W. (2015). Vertical distribution and columnar optical properties of springtime biomassburning aerosols over Northern Indochina during 2014 7-SEAS Campaign. Aerosol Air Qual. Res. 15: 20372050.

WCCAP (2018). http://www.wmo-gaw-wcc-aerosol-phys ics.org/audits.html, Last Access: 06 March 2018.

Weingartner, E., Saathoff, H., Schnaiter, M., Streit, N., Bitnar, B. and Baltensperger, U. (2003). Absorption of light by soot particles: determination of the absorption coefficient by means of aethalometers. J. Aerosol Sci. 34: $1445-1463$.

WMO/GAW (2016). WMO/GAW Aerosol Measurement Procedures, Guidelines and Recommendations, GAW Report 227, World Meteorological Organization, Geneva,
Switzerland.

Yen, M.C., Peng, C.M., Chen, T.C., Chen, C.S., Lin, N.H., Tzeng, R.Y., Lee, Y.A. and Lin, C.C. (2013). Climate and weather characteristics in association with the active fires in northern Southeast Asia and spring air pollution in Taiwan during 2010 7-SEAS/Dongsha Experiment. Atmos. Environ. 78: 35-50.

Yver Kwok, C., Laurent, O., Guemri, A., Philippon, C., Wastine, B., Rella, C.W., Vuillemin, C., Truong, F., Delmotte, M., Kazan, V., Darding, M., Lebègue, B., Kaiser, C., Xueref-Rémy, I. and Ramonet, M. (2015). Comprehensive laboratory and field testing of cavity ring-down spectroscopy analyzers measuring $\mathrm{H}_{2} \mathrm{O}, \mathrm{CO}_{2}$, $\mathrm{CH}_{4}$ and CO. Atmos. Meas. Tech. 8: 3867-3892.

Zanatta, M., Gysel, M., Bukowiecki, N., Müller, T., Weingartner, E., Areskoug, H., Fiebig, M., Yttri, K.E., Mihalopoulos, N., Kouvarakis, G., Beddows, D., Harrison, R.M., Cavalli, F., Putaud, J.P., Spindler, G., Wiedensohler, A., Alastuey, A., Pandolfi, M., Sellegri, K., Swietlicki, E., Jaffrezo, J.L., Baltensperger, U. and Laj, P. (2016). A European aerosol phenomenology-5: Climatology of black carbon optical properties at 9 regional background sites across Europe. Atmos. Environ. 145: 346-364.

Zellweger, C., Steinbacher, M. and Buchmann, B. (2012). Evaluation of new laser spectrometer techniques for insitu carbon monoxide measurements. Atmos. Meas. Tech. 5: 2555-2567.

Zhang, Z.S., Engling, G., Chan, C.Y., Yang, Y.H., Lin, M., Shi, S., He, J., Li, Y.D. and Wang, X.M. (2013). Determination of isoprene-derived secondary organic aerosol tracers (2-methyltetrols) by HPAEC-PAD: Results from size-resolved aerosols in a tropical rainforest. Atmos. Environ. 70: 468-476.

Zieger, P., Aalto, P.P., Aaltonen, V., Äijälä, M., Backman, J., Hong, J., Komppula, M., Krejci, R., Laborde, M., Lampilahti, J., de Leeuw, G., Pfüller, A., Rosati, B., Tesche, M., Tunved, P., Väänänen, R. and Petäjä, T. (2015). Low hygroscopic scattering enhancement of boreal aerosol and the implications for a columnar optical closure study. Atmos. Chem. Phys. 15: 7247-7267.

Zotter, P., Herich, H., Gysel, M., El-Haddad, I., Zhang, Y., Močnik, G., Hüglin, C., Baltensperger, U., Szidat, S. and Prévôt, A.S.H. (2017). Evaluation of the absorption Ångström exponents for traffic and wood burning in the Aethalometer-based source apportionment using radiocarbon measurements of ambient aerosol. Atmos. Chem. Phys. 17: 4229-4249.

Received for review, December 8, 2018 Revised, March 2, 2019 Accepted, March 16, 2019 